\title{
Effects of Ti alloying of AlCrN coatings on thermal stability and oxidation resistance
}

\author{
Rikard Forsén, M P. Johansson, Magnus Odén and Naureen Ghafoor
}

\section{Linköping University Post Print}

\section{Tweet}

N.B.: When citing this work, cite the original article.

Original Publication:

Rikard Forsén, M P. Johansson, Magnus Odén and Naureen Ghafoor, Effects of Ti alloying of AlCrN coatings on thermal stability and oxidation resistance, 2013, Thin Solid Films, (534), , 394-402.

http://dx.doi.org/10.1016/j.tsf.2013.03.003

Copyright: Elsevier

http://www.elsevier.com/

Postprint available at: Linköping University Electronic Press

http://urn.kb.se/resolve?urn=urn:nbn:se:liu:diva-93255 


\section{Effects of Ti alloying of AICrN coatings on thermal}

\section{stability and oxidation resistance}

R. Forsén ${ }^{1 *}$, M. P. Johansson ${ }^{1,2}$, M. Odén ${ }^{1}$ and N. Ghafoor ${ }^{1}$

${ }^{1}$ Nanostructured Materials, Department of Physics, Chemistry and Biology (IFM),

Linköping University, 58183 Linköping, Sweden

${ }^{2}$ Seco Tools AB, 73782 Fagersta, Sweden

* rikfo@ifm.liu.se +4613282753 


\section{Abstract}

Quaternary cubic $\left(\mathrm{Ti}_{\mathrm{x}} \mathrm{Cr}_{1-\mathrm{x}} \mathrm{Al}_{\sim 0.60}\right)_{1} \mathrm{~N}_{1}$ coatings with $0<\mathrm{x}<0.33$ have been grown using reactive cathodic arc evaporation. When adding $\mathrm{Ti}$ the hardness was retained after annealing up to $1100{ }^{\circ} \mathrm{C}$ which is a dramatic improvement compared to $\mathrm{CrAlN}$ coatings. The coatings showed an age hardening process caused by spinodal decomposition into coherent TiCr- and Al-rich cubic TiCrAlN domains and the formation of hexagonal AlN precipitates and cubic $\mathrm{TiCrN}$ domains in the vicinity of the grain boundaries. The improved hardness was attributed to the stabilization of the cubic structure suppressing the formation and growth of hexagonal AlN. Furthermore, the presence of $\mathrm{Ti}$ atoms generated incoherent nanometer-sized crystallites within the hexagonal AlN precipitates disrupting the hexagonal lattice during the coarsening process.

The addition of $\mathrm{Ti}$ promoted the formation of a $\mathrm{TiO}_{2}$ layer over $\mathrm{Al}_{2} \mathrm{O}_{3}$ resulting in a lower oxidation resistance. However, by tuning the composition it is possible to design coatings to have both good oxidation resistance and good high temperature mechanical stability. 


\section{Introduction}

In metal forming and plastic molding operations $\mathrm{CrN}$ coatings are widely used to protect the working tools from corrosion and oxidation [1]. However, the abrasive wear resistance and the hardness of $\mathrm{CrN}$ coatings are low in comparison to other transition metal nitrides and therefore not suited for protection of tools used for metal machining. One way to improve the mechanical properties is to add $\mathrm{Al}$ forming a ternary system [2]. It is possible to deposit metastable cubic (c)-CrAlN coatings with up to $60-70$ at. $\%$ of Al-content [3,4]. If the amount of $\mathrm{Al}$ is higher hexagonal (h)-AlN will form during deposition and the hardness decreases [4]. Since $h$-AlN is a more stable phase there is always a driving force for transformation of the cubic phase into the hexagonal phase. Thus, at elevated temperatures where there is sufficient energy for diffusion the mechanical properties will deteriorate fast. The cubic phase and a high hardness can be

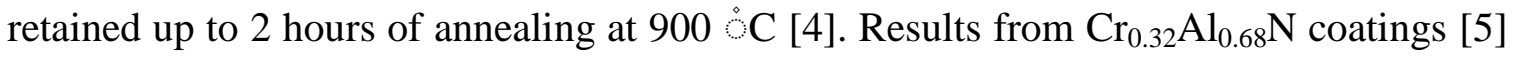
show a weak age hardening process [6,7] due to $h$-AlN precipitation at $\sim 700 \AA \mathrm{C}$ but at higher temperatures the mechanical properties deteriorate.

The performance of coatings for cutting tools depends highly on the hardness and the oxidation resistance at elevated temperatures. Because of temperatures reaching above $1000{ }^{\circ} \mathrm{C}$ at the edge of a cutting tool during metal machining [8], CrAlN coatings are usually inadequate for high-temperature and high-abrasive applications. On the contrary, TiAlN coatings are widely used for metal machining because of its superior mechanical properties at elevated temperatures. However, in terms of corrosion and oxidation resistance CrAlN coatings are superior [9]. In short, there is an opening for functional coatings having both high hardness and good oxidation resistance at elevated 
temperatures. It has been pointed out, that improving thermal stability and oxidation resistance by fine-tuning the composition is a necessity for further advances in hard coating development [10]. Here we aim to do so through a multicomponent alloying concept. In this paper the influence of Ti additions to $c-\mathrm{Cr}_{0.4} \mathrm{Al}_{0.6} \mathrm{~N}$ is investigated and coupled to the phase and microstructure evolution, the high temperature mechanical properties and the oxidation resistance. The results are obtained with scanning transmission electron microscopy (STEM and TEM), nanonindentation, x-ray diffraction (XRD), differential scanning calorimetry (DSC) and thermogravimetric analysis. 


\section{Experimental details}

The coatings were deposited by an industrial Sulzer/Metaplas MZR-323 reactive cathodic arc evaporation system using a combination of different compound cathodes in a $4.5 \mathrm{~Pa}$ $\mathrm{N}_{2}$ atmosphere onto polished WC-Co substrates and Fe foils at $\sim 500{ }^{\circ} \mathrm{C}$ with a substrate bias of $-40 \mathrm{~V}$. The WC-Co substrates and the Fe foils were mounted on a rotating sample fixture $(3 \mathrm{rpm})$ inside the deposition system. The aim was to have an $\mathrm{Al}$ content close to 60 at. $\%$ therefore cathodes containing $\mathrm{Ti}_{29} \mathrm{Cr}_{5} \mathrm{Al}_{66}, \mathrm{Cr}_{33} \mathrm{Al}_{67}, \mathrm{Ti}_{33} \mathrm{Cr}_{33} \mathrm{Al}_{34}$ and $\mathrm{Ti}_{33} \mathrm{Al}_{67}$ were mounted at different heights inside the chamber, yielding different compositions depending on where the substrate is placed in front of the cathodes. After evacuating the chamber to a base pressure of $1 \mathrm{mPa}$ the substrates were sputter cleaned through $\mathrm{Ar}$ bombardment. Deposition for about 2 hours yielded coatings with a thickness of $\sim 3 \mu \mathrm{m}$. See Ref. [11] for more details.

To establish the composition of the coatings a combination of elastic recoil detection analysis (ERDA) and energy-dispersive X-ray spectroscopy EDX was used. ERDA measurements utilized an ${ }^{127} \mathrm{I}^{9+}$ ion beam with incidence angle of $22.5^{\circ}$ and accelerated to $40 \mathrm{MeV}$. A time-of-flight and energy detector (TOF-E ERDA) was used for detection of the ejected species. The concentration ratios between nitrogen, aluminum and the sum of titanium and chromium, $\mathrm{N}: \mathrm{Al}: \mathrm{Ti}+\mathrm{Cr}$, was obtained with ERDA. To establish the Ti:Cr ratio EDX was used instead of ERDA due to the similar mass of titanium and chromium.

The thermal response from the coatings was measured using a Netzsch STA 410 differential scanning calorimeter (DSC). DSC samples were prepared by removal of coated Fe foils through mechanical grinding and subsequent dissolution in concentrated $\mathrm{HCl}(37 \%)$. The remaining coating was filtered cleaned with acetone and crushed to a 
fine powder and approximately $50 \mathrm{mg}$ powder was put in an $\mathrm{Al}_{2} \mathrm{O}_{3}$ crucible used for the measurement. The measurement was conducted by heating the powder up to $1400{ }^{\circ} \mathrm{C}$ at a rate of $20^{\circ} \mathrm{C} / \mathrm{min}$ under a He flow of $50 \mathrm{ml} / \mathrm{min}$. At $1400{ }^{\circ} \mathrm{C}$ the sample was cooled down to room temperature and the heating was repeated. The second heating cycle was used for a base line correction of the thermal response in the first cycle.

The oxidation tests were conducted by heating the powder up to $1100{ }^{\circ} \mathrm{C}$ at a rate of 5 ${ }^{\circ} \mathrm{C} / \mathrm{min}$ and $20^{\circ} \mathrm{C} / \mathrm{min}$ in air at atmospheric pressure while measuring the sample mass.

Post deposition anneals were performed of the coated WC-Co substrates at $\mathrm{T}_{\max }=700$, $800,900,950,1000,1050$ and $1100{ }^{\circ} \mathrm{C}$ in an argon atmosphere at atmospheric pressure using a Sintervac furnace from GCA Vacuum Industries. The samples were annealed with a heating rate of $7{ }^{\circ} \mathrm{C} / \mathrm{min}$ up to $40^{\circ} \mathrm{C}$ below the final annealing temperature, $\mathrm{T}_{\max }$, and then decreased to a rate of $5^{\circ} \mathrm{C} / \mathrm{min}$. $\mathrm{T}_{\max }$ was kept constant for 2 hours and thereafter the samples were cooled down to $500{ }^{\circ} \mathrm{C}$ during 1.5 hours and to $100{ }^{\circ} \mathrm{C}$ in 4 hours. This annealing procedure is the basis of the hardness measurements in Fig. 1. The WC-Co substrates did not withstand annealing temperatures above $1100{ }^{\circ} \mathrm{C}$ without reacting with the coating. Additionally, there are many overlaps in the XRD reflections from substrate and coating making interpretation more difficult. Therefore powder samples obtained from coated foils were heated in vacuum $\left(\sim 10^{-2} \mathrm{~Pa}\right)$ at steps up to $\mathrm{T}_{\max }=$ $700,800,900,950,1000,1050$ and $1100,1200,1300,1350$ and $1400{ }^{\circ} \mathrm{C}$ with a rate of 20 ${ }^{\circ} \mathrm{C} / \mathrm{min}$. In this annealing series the same powder sample was repeatedly heated, cooled to room temperature, measured with $\mathrm{XRD}$ and then heated again to the next higher temperature, see Fig. 3. 
X-Ray $\theta-2 \theta$ diffractograms with a $2 \theta$ range from $20^{\circ}$ to $80^{\circ}$ were obtained with a Panalytical X'Pert PRO MRD X-ray diffractometer using $\mathrm{Cu} \mathrm{K}_{\alpha}$ radiation.

Scanning transmission electron microscopy, transmission electron microscopy, and Xray energy dispersive spectroscopy were performed with a FEI Tecnai $\mathrm{G}^{2}$ TF 20 UT microscope operating at $200 \mathrm{kV}$. For the STEM analysis a high angular annular dark field detector using a camera length of $170 \mathrm{~mm}$ was used. Cross sectional TEM samples were prepared by mechanical grinding and polishing followed by Ar-ion beam milling.

The hardness of the coatings was obtained using an UMIS nanoindenter equipped with a Berkovich diamond tip. Fused silica was used as a reference material to determine the tip shape. Indentation was performed on mechanically polished tapered cross sections of the coatings. The average hardness \pm 1 standard deviation was calculated [12] from approximately 25 indents on each sample using a maximum load of $45 \mathrm{mN}$ with an indentation depth of around $200 \mathrm{~nm}$. 


\section{Results}

The results presented here originates from $\left(\mathrm{Ti}_{\mathrm{x}} \mathrm{Cr}_{\mathrm{y}} \mathrm{Al}_{\mathrm{z}}\right)_{1} \mathrm{~N}_{1}$ coatings covering a metal composition range of $1<\mathrm{x}<33$ at. $\%$ and $\mathrm{z}=\sim 60$ at. $\%$ where all samples contain $50 \pm 1$ at. \% nitrogen in their as-deposited state. Different compositions are presented in order to present the influence of Ti alloying of CrAlN coatings.

\subsection{Mechanical properties}

Figure 1 shows the hardness versus annealing temperature obtained with nanoindentation. For $\mathrm{Ti}_{0.01} \mathrm{Cr}_{0.39} \mathrm{Al}_{0.60} \mathrm{~N}$ coating the hardness decreases with increasing annealing temperature. $\mathrm{Ti}_{0.02} \mathrm{Cr}_{0.38} \mathrm{Al}_{0.60} \mathrm{~N}$ has a constant hardness up to $800{ }^{\circ} \mathrm{C}$ and at $900{ }^{\circ} \mathrm{C}$ the hardness decreases by $\sim 1 \mathrm{GPa}$. The hardness is retained at $1000{ }^{\circ} \mathrm{C}$ and decreases significantly at $1100{ }^{\circ} \mathrm{C}$. For $\mathrm{Ti}_{0.11} \mathrm{Cr}_{0.28} \mathrm{Al}_{0.61} \mathrm{~N}$ the hardness in the as-deposited state is lower compared to the two compositions mentioned above and stays roughly constant up to $900{ }^{\circ} \mathrm{C}$ of annealing. In the $1000{ }^{\circ} \mathrm{C}$ annealed state the hardness increases $\sim 10 \%$ ( 3 GPa) compared to the as-deposited state. At $1100{ }^{\circ} \mathrm{C}$ the hardness decreases to the same level as its as-deposited state, i.e. this composition retains its hardness to considerably higher temperatures compared to the 1 and 2 at. \% Ti-containing coatings. Our previous studies show that with 31 at. \% Ti-content the age hardening initiates at a lower temperature of $850^{\circ} \mathrm{C}$ and is retained over a wider temperature range up to $1000{ }^{\circ} \mathrm{C}[11$, 13]. Surprisingly, both the 31 and 11 at. \% Ti-containing coatings show similar high hardness at $1100{ }^{\circ} \mathrm{C}$.

As references the hardness values of $\mathrm{Ti}_{0.33} \mathrm{Al}_{0.67} \mathrm{~N}$ [14] and $\mathrm{Cr}_{0.32} \mathrm{Al}_{0.68} \mathrm{~N}$ [5] coatings grown under similar conditions are also shown in Fig. 1. The age hardening is more 
pronounced for $\operatorname{Ti}_{0.33} \mathrm{Al}_{0.67} \mathrm{~N}$ compared to the other coatings, but the hardness between 1000 and $1100{ }^{\circ} \mathrm{C}$ is significantly lower compared to the 31 and 11 at. \% Ti-containing coatings. 


\subsection{Phase evolution and thermal stability}

Figure 2 shows the in-situ DSC measurements of the thermal response of $\mathrm{Ti}_{0.11} \mathrm{Cr}_{0.28} \mathrm{Al}_{0.61} \mathrm{~N}, \mathrm{Ti}_{0.02} \mathrm{Cr}_{0.38} \mathrm{Al}_{0.60} \mathrm{~N}$ and $\mathrm{Ti}_{0.01} \mathrm{Cr}_{0.39} \mathrm{Al}_{0.60} \mathrm{~N}$ during heating up to $1400{ }^{\circ} \mathrm{C}$ with a heating rate of $20{ }^{\circ} \mathrm{C} / \mathrm{min}$. The right axis shows the relative mass change of the coatings during the heating process. Observed peaks in the thermal response have been numbered and marked on the temperature axis corresponding to the maximum slope of the thermal response. The exothermic peak located at $\mathrm{T}_{1}=\sim 600{ }^{\circ} \mathrm{C}$ is observed for $\mathrm{Ti}_{0.01} \mathrm{Cr}_{0.39} \mathrm{Al}_{0.60} \mathrm{~N}$ and $\mathrm{Ti}_{0.02} \mathrm{Cr}_{0.38} \mathrm{Al}_{0.60} \mathrm{~N}$. A peak at $\mathrm{T}_{2}=\sim 800{ }^{\circ} \mathrm{C}$ is only observed for $\mathrm{Ti}_{0.01} \mathrm{Cr}_{0.39} \mathrm{Al}_{0.60} \mathrm{~N}$. There is an exothermic peak at $\mathrm{T}_{3}=\sim 1000{ }^{\circ} \mathrm{C}$ present in $\mathrm{Ti}_{0.02} \mathrm{Cr}_{0.38} \mathrm{Al}_{0.60} \mathrm{~N}$. The exothermic peak at $\mathrm{T}_{4}=\sim 1150{ }^{\circ} \mathrm{C}$ is observed for all three compositions but is located at $\sim 50{ }^{\circ} \mathrm{C}$ higher temperature for $\mathrm{Ti}_{0.11} \mathrm{Cr}_{0.28} \mathrm{Al}_{0.61} \mathrm{~N}$. All three compositions exhibit an exothermic peak at $\mathrm{T}_{5}=\sim 1275^{\circ} \mathrm{C}$ and an endothermic peak at $\mathrm{T}_{6}$ $=\sim 1325^{\circ} \mathrm{C}$ which is located at $\sim 25^{\circ} \mathrm{C}$ higher temperature for $\operatorname{Ti}_{0.11} \mathrm{Cr}_{0.28} \mathrm{Al}_{0.61} \mathrm{~N}$. Close to $\mathrm{T}_{7}=\sim 1375^{\circ} \mathrm{C}$ all three compositions exhibit an exothermic reaction.

At $\mathrm{T}_{3}=\sim 1000{ }^{\circ} \mathrm{C}$ the mass starts to decrease for all three compositions. The rate of the mass loss is lower for $\mathrm{Ti}_{0.11} \mathrm{Cr}_{0.28} \mathrm{Al}_{0.61} \mathrm{~N}$ but increases at $\mathrm{T}_{5}=\sim 1275{ }^{\circ} \mathrm{C}$. At $1400{ }^{\circ} \mathrm{C}$ the total mass loss is $\sim 8 \%$ for $\mathrm{Ti}_{0.11} \mathrm{Cr}_{0.28} \mathrm{Al}_{0.61} \mathrm{~N}, \sim 7 \%$ for $\mathrm{Ti}_{0.01} \mathrm{Cr}_{0.39} \mathrm{Al}_{0.60} \mathrm{~N}$ and $\mathrm{Ti}_{0.02} \mathrm{Cr}_{0.38} \mathrm{Al}_{0.60} \mathrm{~N}$. 
Figure 3 shows x-ray diffractograms of $\mathrm{Ti}_{0.01} \mathrm{Cr}_{0.39} \mathrm{Al}_{0.60} \mathrm{~N}$ (a) and $\mathrm{Ti}_{0.11} \mathrm{Cr}_{0.28} \mathrm{Al}_{0.61} \mathrm{~N}$ (b) in the $2 \theta$ range from $32^{\circ}$ to $45^{\circ}$ and from $66^{\circ}$ to $78^{\circ}$ at different temperatures.

The retention of solid solution $c$-TiCrAlN is most clearly seen at $2 \theta=\sim 76^{\circ}$. For both samples there is initially a shift to higher angles upon heating to $700{ }^{\circ} \mathrm{C}$ indicative of stress relaxation. Thereafter there is a reduction of the full width maximum when the samples are heated up to $1000{ }^{\circ} \mathrm{C}$ consistent with crystal recovery and grain growth. Above $1000{ }^{\circ} \mathrm{C}$ the intensity begins to decrease. The decrease is more pronounced for $\mathrm{Ti}_{0.01} \mathrm{Cr}_{0.39} \mathrm{Al}_{0.60} \mathrm{~N}$ and at $1200{ }^{\circ} \mathrm{C}$ the peak is barely detectable whereas for $\mathrm{Ti}_{0.11} \mathrm{Cr}_{0.28} \mathrm{Al}_{0.61} \mathrm{~N}$ it is still clearly seen.

$h$-AlN can be detected at $2 \theta=33.2^{\circ}$ and at $2 \theta=36^{\circ}$ in both samples but the reflections are more pronounced in $\mathrm{Ti}_{0.01} \mathrm{Cr}_{0.39} \mathrm{Al}_{0.60} \mathrm{~N}$. For $\mathrm{Ti}_{0.01} \mathrm{Cr}_{0.39} \mathrm{Al}_{0.60} \mathrm{~N}$ the presence of $h$-AIN can be seen at $900{ }^{\circ} \mathrm{C}$ and for $\mathrm{Ti}_{0.11} \mathrm{Cr}_{0.28} \mathrm{Al}_{0.61} \mathrm{~N}$ it is detected at $950{ }^{\circ} \mathrm{C}$. Between $900{ }^{\circ} \mathrm{C}$ and $1400{ }^{\circ} \mathrm{C}$ the intensity of these reflections increases and the full width maximum is reduced as larger $h$-AlN domains form. The reduction of the full width half maximum is more pronounced in $\mathrm{Ti}_{0.01} \mathrm{Cr}_{0.39} \mathrm{Al}_{0.60} \mathrm{~N}$ between $950{ }^{\circ} \mathrm{C}$ and $1200{ }^{\circ} \mathrm{C}$, i.e. the $h$-AlN domains grow faster, and at $1400{ }^{\circ} \mathrm{C}$ the full width maximum in $\mathrm{Ti}_{0.01} \mathrm{Cr}_{0.39} \mathrm{Al}_{0.60} \mathrm{~N}$ is still smaller.

Hexagonal $\beta-\mathrm{Cr}_{2} \mathrm{~N}$ can be seen at $2 \theta=43.4^{\circ}$ between $950{ }^{\circ} \mathrm{C}$ and $1100{ }^{\circ} \mathrm{C}$ in $\mathrm{Ti}_{0.01} \mathrm{Cr}_{0.39} \mathrm{Al}_{0.60} \mathrm{~N}$. In $\mathrm{Ti}_{0.11} \mathrm{Cr}_{0.28} \mathrm{Al}_{0.61} \mathrm{~N}$ it shows up as a weak peak between $1100{ }^{\circ} \mathrm{C}$ $1200^{\circ} \mathrm{C}$.

$c$-TiN is detected in $\mathrm{Ti}_{0.11} \mathrm{Cr}_{0.28} \mathrm{Al}_{0.61} \mathrm{~N}$ at for example $2 \theta=42.6^{\circ}$ between $1300{ }^{\circ} \mathrm{C}$ and $1400{ }^{\circ} \mathrm{C}$ with a decreasing full width half maximum. This reflection is also weakly detected in $\mathrm{Ti}_{0.01} \mathrm{Cr}_{0.39} \mathrm{Al}_{0.60} \mathrm{~N}$ at $1400{ }^{\circ} \mathrm{C}$. 
bcc-Cr can be detected in both samples between $1300{ }^{\circ} \mathrm{C}$ and $1400{ }^{\circ} \mathrm{C}$ seen from the increasing peak intensities close to $2 \theta=44.4^{\circ}$.

At $1350{ }^{\circ} \mathrm{C}$ and $1400{ }^{\circ} \mathrm{C}$ weak peaks belonging to $\alpha-\mathrm{Al}_{2} \mathrm{O}_{3}$ are detected in both samples.

Fig. 3 (c) contains a schematic summary of the phase evolution for $\mathrm{Ti}_{0.01} \mathrm{Cr}_{0.39} \mathrm{Al}_{0.60} \mathrm{~N}$ and $\mathrm{Ti}_{0.11} \mathrm{Cr}_{0.28} \mathrm{Al}_{0.61} \mathrm{~N}$. 


\subsection{Structure evolution}

Results of the coatings in their as deposited states revealed a dense columnar growth with high concentrations of defects (not shown). Figure 4 (a) and (b) show overview STEM Zcontrast micrographs of $\mathrm{Ti}_{0.11} \mathrm{Cr}_{0.28} \mathrm{Al}_{0.61} \mathrm{~N}$ and $\mathrm{Ti}_{0.01} \mathrm{Cr}_{0.39} \mathrm{Al}_{0.60} \mathrm{~N}$ annealed at $900{ }^{\circ} \mathrm{C}$ for 2 hours. For $\mathrm{Ti}_{0.01} \mathrm{Cr}_{0.39} \mathrm{Al}_{0.60} \mathrm{~N}$ (a) it is clear that annealing at $900{ }^{\circ} \mathrm{C}$ has resulted in a pronounced elemental segregation in the grain boundaries extending from the substrate up to the surface of the coating. For $\mathrm{Ti}_{0.11} \mathrm{Cr}_{0.28} \mathrm{Al}_{0.61} \mathrm{~N}$ the segregation is less pronounced with smaller domain sizes and not extending all the way from the surface down to the substrate. From EDX analysis it is revealed that the grain boundaries are AlN-enriched, see Fig. 7. 
Figure 5 (a) shows a Z-contrast micrograph obtained from a grain interior for $\mathrm{Ti}_{0.11} \mathrm{Cr}_{0.28} \mathrm{Al}_{0.61} \mathrm{~N}$ annealed at $900{ }^{\circ} \mathrm{C}$. It can be seen that at $900{ }^{\circ} \mathrm{C}$ the elemental distribution within the grains is not homogeneous. The Z-contrast in the image depicts elemental segregation into 1-3 nm sized domains containing Al-rich $c$-TiCrAlN with lower mass (dark regions) and $\mathrm{TiCr}$-rich $c$-TiCrAlN with higher mass (bright regions). No reliable quantification of these fluctuations could be obtained with the available instrument since the domain size is too small. Fig. 5 (b) depicts a high resolution micrograph with higher magnification from the same region. It can be seen that the lattice is coherent across the domains. The average lattice spacing within each domain, i.e. Aland TiCr-rich $c$-TiCrAlN, showed a variation of $\sim 2 \%$.

Figure 6 (a) and (b) show overview micrographs of $\mathrm{Ti}_{0.11} \mathrm{Cr}_{0.28} \mathrm{Al}_{0.61} \mathrm{~N}$ annealed at 1000 ${ }^{\circ} \mathrm{C}$. Fig. 6 (a) depicts a diffraction contrast micrograph and Fig. 6 (b) depicts a Z-contrast micrograph obtained from the same region. A $~ 1.3 \mu \mathrm{m}$ long grain along the growth direction seen in the diffraction contrast micrograph is surrounded by lighter elements (Al) as depicted from the Z-contrast micrograph (indicated by arrows). Thus at $1000{ }^{\circ} \mathrm{C}$, the $h$-AlN segregation is more pronounced compared to $900{ }^{\circ} \mathrm{C}$ (Fig. 4) and completely encapsulates the grains in the coating extending from the surface to the substrate. 
Figure 7 (a) shows a high resolution TEM micrograph obtained close to a grain boundary of $\mathrm{Ti}_{0.11} \mathrm{Cr}_{0.28} \mathrm{Al}_{0.61} \mathrm{~N}$ annealed at $1000{ }^{\circ} \mathrm{C}$. The lower insets show maps from the same area depicting the characteristic $\mathrm{x}$-ray signals from $\mathrm{Al}$, $\mathrm{Ti}$ and $\mathrm{Cr}$ respectively. Fig. 7 (b) depicts results from an EDX line scan across a grain boundary as indicated by the red line across the dark region in the Z-contrast micrograph. From the scans it is clear that the elements are not homogeneously distributed in the coating after the annealing. The results show that in the grain boundaries there are $15-30 \mathrm{~nm}$ sized Al-rich and Cr-depleted TiCrAlN domains containing traces of Ti. Additionally, there are $\sim 5 \mathrm{~nm}$ sized regions of almost Al-depleted TiCr-rich TiCrAlN, see areas marked with circles in Figs. 7 (a) and (b). These domains which are located in the grain boundaries are surrounded by grains containing compositional fluctuations corresponding to coherent 1-4 nm sized TiCr- and Al-rich TiCrAlN domains, see Figs. 5 and 8.

Figure 8 shows a high resolution micrograph obtained at a grain boundary in $\mathrm{Ti}_{0.11} \mathrm{Cr}_{0.28} \mathrm{Al}_{0.61} \mathrm{~N}$ annealed at $1000{ }^{\circ} \mathrm{C}$. The upper part in the figure depicts a grain interior separated from the grain boundary by the solid white line. The grain interior exhibits 1-4 nm sized TiCr- and Al-rich $c$-TiCrAlN domains, i.e. not significantly larger than the size observed at $900{ }^{\circ} \mathrm{C}$ (Fig. 5). In the inset to the upper right the Fourier transform generated from the upper domain is depicted. It reveals one single coherent cubic phase [111] similar to $900{ }^{\circ} \mathrm{C}$. The lower part in the figure separated by the white solid line depicts a grain boundary containing $h$-(Ti)AlN. This domain is Cr-depleted but contains some traces of Ti (see Fig. 7). The lattice in the $h$-(Ti)AlN phase is disrupted by several 5-10 nm sized crystallites with different orientations. These crystallites are 
indicated by the dashed white lines. Along the domain boundaries (the solid white line) the lattice is incoherent.

In summary, upon annealing, the elements in the $\mathrm{Ti}_{0.11} \mathrm{Cr}_{0.28} \mathrm{Al}_{0.61} \mathrm{~N}$ coating have segregated forming a complex structure containing $h$-(Ti)AlN and $c$-TiCrN domains located in the grain boundaries and the grains are decomposed into coherent $\mathrm{TiCr}$ and $\mathrm{Al}-$ rich $c$-TiCrAlN domains. With increasing annealing temperature the size and volume fraction of the Al-enriched domains in the grain boundaries increases. At $1100{ }^{\circ} \mathrm{C}$, they are contributing to approximately $50 \%$ of the total volume with a size of $50-75 \mathrm{~nm}$ (value determined from TEM observations). The size of the Al-depleted TiCr-rich domains located in the grain boundaries is also increasing at higher annealing temperatures to around $15-20 \mathrm{~nm}$ at $1100{ }^{\circ} \mathrm{C}$. The size of the compositional fluctuations present in the grain interiors, i.e. the TiCr- and Al-rich $c$-TiCrAlN domains, does not show any significant increase from $1-3 \mathrm{~nm}$ at $900{ }^{\circ} \mathrm{C}$ compared to $2-5 \mathrm{~nm}$ at $1100{ }^{\circ} \mathrm{C}$. Figure 9 shows a summary of the structure evolution up to $1100^{\circ} \mathrm{C}$. 


\subsection{Oxidation resistance}

Figure 10 shows in-situ measurements of the mass change of $\operatorname{Ti}_{0.33} \mathrm{Al}_{0.67} \mathrm{~N}$, $\mathrm{Ti}_{0.31} \mathrm{Cr}_{0.07} \mathrm{Al}_{0.62} \mathrm{~N}, \mathrm{Ti}_{0.11} \mathrm{Cr}_{0.28} \mathrm{Al}_{0.61} \mathrm{~N}, \mathrm{Ti}_{0.02} \mathrm{Cr}_{0.38} \mathrm{Al}_{0.60} \mathrm{~N}$ and $\mathrm{Ti}_{0.01} \mathrm{Cr}_{0.39} \mathrm{Al}_{0.60} \mathrm{~N}$ during heating in air up to $1100{ }^{\circ} \mathrm{C}$ with a heating rate of $5{ }^{\circ} \mathrm{C} / \mathrm{min}$. The mass of the samples is approximately constant up to $\sim 800^{\circ} \mathrm{C}$ for all compositions. At higher temperatures the mass starts to increase more significantly, indicative of oxidation. The onset for oxidation seems to occur at $\sim 900{ }^{\circ} \mathrm{C}$ for $\mathrm{Ti}_{0.31} \mathrm{Cr}_{0.07} \mathrm{Al}_{0.62} \mathrm{~N}, \sim 950{ }^{\circ} \mathrm{C}$ for $\mathrm{Ti}_{0.33} \mathrm{Al}_{0.67} \mathrm{~N}$ and at $\sim 1000$ ${ }^{\circ} \mathrm{C}$ for $\mathrm{Ti}_{0.11} \mathrm{Cr}_{0.28} \mathrm{Al}_{0.61} \mathrm{~N}$. $\mathrm{Ti}_{0.02} \mathrm{Cr}_{0.38} \mathrm{Al}_{0.60} \mathrm{~N}$ and $\mathrm{Ti}_{0.01} \mathrm{Cr}_{0.39} \mathrm{Al}_{0.60} \mathrm{~N}$ do not show any significant mass increase. The mass gains starts to accelerate for $\mathrm{Ti}_{0.31} \mathrm{Cr}_{0.07} \mathrm{Al}_{0.62} \mathrm{~N}$ close to $975^{\circ} \mathrm{C}$.

At $1100{ }^{\circ} \mathrm{C}$ the mass appears to stabilize at $\sim 124 \%$ for $\mathrm{Ti}_{0.33} \mathrm{Al}_{0.67} \mathrm{~N}$, at $\sim 123 \%$ for $\mathrm{Ti}_{0.31} \mathrm{Cr}_{0.07} \mathrm{Al}_{0.62} \mathrm{~N}$ and at $\sim 116 \%$ for $\mathrm{Ti}_{0.11} \mathrm{Cr}_{0.28} \mathrm{Al}_{0.61} \mathrm{~N}$. The mass increase of $\mathrm{Ti}_{0.01} \mathrm{Cr}_{0.39} \mathrm{Al}_{0.60} \mathrm{~N}$ and $\mathrm{Ti}_{0.02} \mathrm{Cr}_{0.38} \mathrm{Al}_{0.60} \mathrm{~N}$ at $1100{ }^{\circ} \mathrm{C}$ is $\sim 4 \%$.

The inset in Fig. 10 shows the relative mass change for $\mathrm{Ti}_{0.01} \mathrm{Cr}_{0.39} \mathrm{Al}_{0.60} \mathrm{~N}$ and $\mathrm{Ti}_{0.11} \mathrm{Cr}_{0.28} \mathrm{Al}_{0.61} \mathrm{~N}$ using a heating rate of $20{ }^{\circ} \mathrm{C} / \mathrm{min}$. Both $\mathrm{Ti}_{0.11} \mathrm{Cr}_{0.28} \mathrm{Al}_{0.61} \mathrm{~N}$ and $\mathrm{Ti}_{0.01} \mathrm{Cr}_{0.39} \mathrm{Al}_{0.60} \mathrm{~N}$ show similar amount of mass increase up to $1000{ }^{\circ} \mathrm{C}$. At $1000{ }^{\circ} \mathrm{C}$ the mass increase of $\mathrm{Ti}_{0.11} \mathrm{Cr}_{0.28} \mathrm{Al}_{0.61} \mathrm{~N}$ begins to accelerate, due to the onset of oxidation. For this heating rate at $1100{ }^{\circ} \mathrm{C}$ the mass has increased $\sim 4 \%$ for $\mathrm{Ti}_{0.11} \mathrm{Cr}_{0.28} \mathrm{Al}_{0.61} \mathrm{~N}$ and $\sim 3 \%$ for $\mathrm{Ti}_{0.01} \mathrm{Cr}_{0.39} \mathrm{Al}_{0.60} \mathrm{~N}$. 
Figure 11 shows x-ray diffractograms obtained from $\operatorname{Ti}_{0.33} \mathrm{Al}_{0.67} \mathrm{~N}, \mathrm{Ti}_{0.11} \mathrm{Cr}_{0.28} \mathrm{Al}_{0.61} \mathrm{~N}$, $\mathrm{Ti}_{0.31} \mathrm{Cr}_{0.07} \mathrm{Al}_{0.62} \mathrm{~N}, \mathrm{Ti}_{0.02} \mathrm{Cr}_{0.38} \mathrm{Al}_{0.60} \mathrm{~N}$ and $\mathrm{Ti}_{0.01} \mathrm{Cr}_{0.39} \mathrm{Al}_{0.60} \mathrm{~N}$ in the $2 \theta$ range from $25^{\circ}$ to $60^{\circ}$ obtained after heating in air up to $1100^{\circ} \mathrm{C}$ with a heating rate of $5^{\circ} \mathrm{C} / \mathrm{min}$. Among these compositions there is a clear trend in the oxidation behavior with increasing $\mathrm{Ti}$ content.

For $\mathrm{Ti}_{0.01} \mathrm{Cr}_{0.39} \mathrm{Al}_{0.60} \mathrm{~N}$ no phases apart from $h$-AlN and $c$-TiCrAlN are detectable.

For $\mathrm{Ti}_{0.02} \mathrm{Cr}_{0.38} \mathrm{Al}_{0.60} \mathrm{~N}$ faint peaks originating from $\alpha-(\mathrm{CrAl})_{2} \mathrm{O}_{3}$ are seen for example at $2 \theta=25.6^{\circ}$ indicative of a thin oxide layer. Strong peaks belonging to $h$-AlN and $c$ TiCrAlN are also detected.

When the Ti content is increased to 11 at. $\%, \mathrm{Ti}_{0.11} \mathrm{Cr}_{0.28} \mathrm{Al}_{0.61} \mathrm{~N}$, strong peaks from $\mathrm{TiO}_{2}$ and $\alpha-(\mathrm{CrAl})_{2} \mathrm{O}_{3}$ are detected. The peaks belonging to $\alpha-(\mathrm{CrAl})_{2} \mathrm{O}_{3}$ are asymmetric which is clearly seen for example at $2 \theta=52.5^{\circ}$. This suggests convoluted peaks originating from $\alpha-\mathrm{Al}_{2} \mathrm{O}_{3}, \alpha-\mathrm{Cr}_{2} \mathrm{O}_{3}$ and $\alpha-(\mathrm{CrAl})_{2} \mathrm{O}_{3}$. Weak peaks belonging to $h$-AlN and $c$-TiCrAlN are also detected. In $\mathrm{Ti}_{0.31} \mathrm{Cr}_{0.07} \mathrm{Al}_{0.62} \mathrm{~N}$ the peaks originating from $\alpha-(\mathrm{CrAl})_{2} \mathrm{O}_{3}$ are weaker and symmetric indicative of a thin $\alpha-(\mathrm{CrAl})_{2} \mathrm{O}_{3}$ layer with low $\mathrm{Cr}$ content. The peaks belonging to $\mathrm{TiO}_{2}$ are stronger with a reduced half width maximum suggesting larger oxide-grains compared to $\mathrm{TiO}_{2}$ in $\mathrm{Ti}_{0.11} \mathrm{Cr}_{0.28} \mathrm{Al}_{0.61} \mathrm{~N}$. No peaks belonging to any nitrides ( $c$-TiCrAlN nor $h$-AlN) are detected suggesting a complete oxidation of the powder.

For $\mathrm{Ti}_{0.33} \mathrm{Al}_{0.67} \mathrm{~N}$ the trend continues and the dominating peaks belong to $\mathrm{TiO}_{2}$ with an even further reduced half width maximum. Weak peaks belonging $\alpha-\mathrm{Al}_{2} \mathrm{O}_{3}$ are also detected while no nitride phases are detected. 


\section{Discussion}

\subsection{Phase stability and hardness}

The coatings contain a defect-rich structure in the as-deposited state generating high stresses and a high hardness. Upon annealing at $700{ }^{\circ} \mathrm{C}$, the coatings exhibit compressive stress relaxation and recovery processes. These processes normally lead to a hardness decrease frequently observed in arc evaporated coatings [14,15]. This can also be related to the thermal response exhibiting an exothermic peak at $\mathrm{T}_{1} \approx 600{ }^{\circ} \mathrm{C}$ which is around 100 ${ }^{\circ} \mathrm{C}$ above the deposition temperature. For $\mathrm{Ti}_{0.11} \mathrm{Cr}_{0.28} \mathrm{Al}_{0.61} \mathrm{~N}$ the stress relaxation is less pronounced, the corresponding exothermic peak at $\mathrm{T}_{1} \approx 600{ }^{\circ} \mathrm{C}$ is suppressed and the hardness is more or less constant up to $700{ }^{\circ} \mathrm{C}$. This indicates that the stress in the as deposited state is lower for this composition explaining the lower hardness compared to the coatings with 1 and 2 at. \% Ti. But even though the hardness in the as-deposited state is lower for $\mathrm{Ti}_{0.11} \mathrm{Cr}_{0.28} \mathrm{Al}_{0.61} \mathrm{~N}$ the hardness at temperatures between 1000 and $1100{ }^{\circ} \mathrm{C}$ is significantly higher.

Age hardening has previously been reported and attributed to the formation of $h$-AlN precipitates at the grain boundaries in $\mathrm{Cr}_{0.32} \mathrm{Al}_{0.68} \mathrm{~N}$ [5]. The hardness increase in that case occurred at $\sim 700{ }^{\circ} \mathrm{C}$ and was within one standard deviation of the measurement. At 900 ${ }^{\circ} \mathrm{C}$ the size and volume fraction of the $h$-AlN precipitates increased which resulted in a hardness decrease. As shown in this work, the age hardening effect can be improved through $\mathrm{Ti}$ addition in terms of a greater magnitude and a wider temperature range. The effects of Ti addition on the phase evolution can be directly coupled to the in-situ measurements of the thermal response of the coatings. The thermal response contains the sum of all exothermic and endothermic reactions occurring in the sample where the true 
location and magnitude of individual contributions related to a certain reaction can be difficult to separate or can be completely cancelled out due to co-occurring reactions. But by using the combined information from XRD results and previously published measurements of the thermal response of pure CrAlN [16] it is possible to identify the peaks.

With 1 at. $\% \mathrm{Ti}$ addition, $\mathrm{Ti}_{0.01} \mathrm{Cr}_{0.39} \mathrm{Al}_{0.60} \mathrm{~N}$, the sample shows similarly to pure $\mathrm{Cr}_{0.32} \mathrm{Al}_{0.68} \mathrm{~N}$ a $300{ }^{\circ} \mathrm{C}$ wide strong exothermic reaction peaking at $\mathrm{T}_{2} \approx 800{ }^{\circ} \mathrm{C}$ corresponding to the formation and growth of $h$-AlN [16]. With 2 and 11 at. \% Ti no exothermic peak can be seen at the same temperature. This is in agreement with a reduced $h$-AlN growth rate as seen from the XRD and STEM results. With 2 at. $\% \mathrm{Ti}$ there is an exothermic peak at a temperature of $\mathrm{T}_{3} \approx 1000{ }^{\circ} \mathrm{C}$ probably due to an accelerated $h$-AlN growth.

An endothermic reaction related to the release of chromium-bonded nitrogen is seen as strong peaks close to $\mathrm{T}_{6} \approx 1300{ }^{\circ} \mathrm{C}$. But the nitrogen release and consequently also an endothermic contribution is initiated already at $\mathrm{T}_{3} \approx 1000{ }^{\circ} \mathrm{C}$, seen from the negative mass change. This is the reason behind the negative trends in the thermal response seen above $\mathrm{T}_{3} \approx 1000{ }^{\circ} \mathrm{C}$ for the samples with 1 and 2 at. $\%$ Ti.

For the higher Ti-containing (11 at. \%) coating it appears as the nitrogen vacancy formation is less energetically favorable, which results in the observed lower nitrogen release rate between $\mathrm{T}_{3} \approx 1000{ }^{\circ} \mathrm{C}$ and $\mathrm{T}_{5} \approx 1300{ }^{\circ} \mathrm{C}$. It also shifts the exothermic reaction originating from the transformation of $c$ - $\mathrm{CrN}$ into $\beta$ - $\mathrm{Cr}_{2} \mathrm{~N}$ at $\mathrm{T}_{4}=\sim 1150{ }^{\circ} \mathrm{C}[16]$ to $\sim 50{ }^{\circ} \mathrm{C}$ higher temperatures. The lower nitrogen release for this composition is supported by our previously published theoretical results predicting a minimum in the free energy of $c$ - 
$\mathrm{Ti}_{\sim 0.1} \mathrm{Cr}_{\sim 0.9} \mathrm{~N}$ in comparison to pure $c$-CrN at elevated temperatures. [13] Furthermore, for CrAlN coatings it has been suggested that the stoichiometry reaches $\mathrm{CrN}_{0.5}$ before transforming into $\beta-\mathrm{Cr}_{2} \mathrm{~N}$ [16]. Thus, the presence of Ti strengthens the nitrogen bonds and thereby the cubic structure is stabilized which is confirmed by XRD. This also explains the presence of the cubic nanometer-sized TiCr-rich $c$-TiCrAlN domains observed at temperatures between 1000 and $1100{ }^{\circ} \mathrm{C}$.

It has been shown that the size of the $h$-AlN precipitates in CrAlN coatings or the size of the compositional fluctuations in TiAlN and TiCrAlN play an important role in terms of the hardness $[5-7,11]$. When a critical size of the $h$-AlN precipitates is reached the hardness decreases $[5,16]$ or when a critical size of the Al-rich TiAlN or TiCrAlN $(\mathrm{Cr}<$ at. $17 \%$ ) domains is reached $c$-AlN transforms into $h$-AlN and the hardness decreases $[6,7,11,17]$. Thus, the suppressed growth of the $h$-AlN phase and the increased stability of the cubic phase for $\mathrm{Ti}_{0.11} \mathrm{Cr}_{0.28} \mathrm{Al}_{0.61} \mathrm{~N}$ explain the less pronounced hardness decrease for this composition at elevated temperatures. The distorted $h$-(Ti)AlN lattice caused by the presence of $\mathrm{Ti}$ atoms probably also contributes to less pronounced detrimental effects associated with the $h$-AlN phase. The hardness increase at $1000{ }^{\circ} \mathrm{C}$ can similarly to TiAlN and TiCrAlN coatings $(\mathrm{Cr}<$ at. $17 \%)$ be attributed to the stress generated by the coherent $\mathrm{Ti}$ - or TiCr- and Al- segregation obstructing dislocation movement $[6,7,11,17]$. 


\subsection{Decomposition mechanisms}

There are two co-occurring and competing decomposition mechanisms that are responsible for the higher hardness at elevated temperatures of $\mathrm{Ti}_{0.11} \mathrm{Cr}_{0.28} \mathrm{Al}_{0.61} \mathrm{~N}$ compared to the coatings with less Ti. One mechanism is the precipitation and growth of $h$-AlN domains at the grain boundaries, which is the observed decomposition route in CrAlN coatings [5]. The other mechanism is the spinodal decomposition of the grain interiors into $\mathrm{TiCr}$ - and Al-rich $c$-TiCrAlN domains similar to the observed decomposition route in TiAlN coatings $[6,7,17]$ or in TiCrAlN coatings [11] (up to 17 at. $\% \mathrm{Cr}$ ). Theoretical results show that there is a higher miscibility gap between $\mathrm{TiN}$ and AlN compared to $\mathrm{CrN}$ and $\mathrm{AlN}$ [18]. Theoretical results also predict a lower free energy in $c-\mathrm{Ti}_{\mathrm{x}} \mathrm{Cr}_{\mathrm{y}} \mathrm{Al}_{0.6} \mathrm{~N}$ coatings for compositions around $\mathrm{y}=0.4$ compared to $\mathrm{x}=0.4[13,18]$. However, to evaluate the stability of these coatings, the second derivative of the free energy should be investigated, i.e. the driving force for spinodal decomposition. If the second derivative is negative the decomposition may occur spontaneously without any requirement of nucleation. Theoretical and experimental results have recently shown that by replacing the $\mathrm{Ti}$ atoms in $c$ - $\mathrm{TiCrAl}_{0.5-0.6} \mathrm{~N}$ with up to 17 at. $\% \mathrm{Cr}$ the driving force for spinodal decomposition is reduced [11]. It was also reported that when the Cr-content was increased from 7 to 17 at. $\%$ formation of $h$-AlN precipitates occurred at the grain boundaries [11]. However, the $h$-AlN precipitation was less pronounced and showed smaller volume fractions at temperatures between $900{ }^{\circ} \mathrm{C}$ and $1100{ }^{\circ} \mathrm{C}$ in comparison to $\mathrm{Ti}_{0.11} \mathrm{Cr}_{0.28} \mathrm{Al}_{0.61} \mathrm{~N}$. Thus, when depositing $c-\mathrm{Ti}_{\mathrm{x}} \mathrm{Cr}_{1-\mathrm{x}} \mathrm{Al} \sim_{0.6} \mathrm{~N}$ coatings there is a transition of the decomposition process from nucleation and growth process of $h$-AlN precipitates at the grain boundaries for $\mathrm{x}=0$ to a spinodal decomposition of the grain interiors into 
$\mathrm{Ti}(\mathrm{Cr})$ - and Al-rich $c-\mathrm{Ti}(\mathrm{Cr}) \mathrm{AlN}$ for $\mathrm{x}=\sim 1$. For compositions where $0<\mathrm{x}<1$ these two decomposition mechanisms are co-occurring but one may dominate over the other depending on $\mathrm{x}$. Furthermore, in agreement with theoretical work the driving force for spinodal decomposition in $c-\mathrm{Cr}_{0.4} \mathrm{Al}_{0.6} \mathrm{~N}$ is significantly increased by adding just relatively small amounts of $\mathrm{Ti}$, i.e. the second derivative decreases significantly [13]. Thus, for $\mathrm{x}=0.11, \mathrm{Ti}_{0.11} \mathrm{Cr}_{0.28} \mathrm{Al}_{0.61} \mathrm{~N}$, a spinodal decomposition is indeed expected.

Strictly speaking, because these calculations of the free energy are performed for the case of randomly distributed atoms the predictions regarding the driving force for spinodal decomposition become invalid as soon the coating begins to decompose and the atoms cluster. But from the calculations it is clear that $c$-TiCrN coatings exhibit close to zero or negative mixing enthalpies at elevated temperatures [13]. Thus, we propose that, during the spinodal decomposition into coherent TiCr- and Al-rich TiCrAlN domains in $\mathrm{Ti}_{0.11} \mathrm{Cr}_{0.28} \mathrm{Al}_{0.61} \mathrm{~N}$ the free energy is significantly lowered compared to the as-deposited state. This reduces the driving force for $\mathrm{Al}$ segregation towards the grain boundaries and consequently $h$-AlN formation. Furthermore, with a lowered driving force for spinodal decomposition, after some initial segregation, it takes longer time for the compositional amplitude to develop (the elemental enrichment) which delays the coarsening stage [11]. This explains why the TiCr- and Al-rich $c$-TiCrAlN fluctuations within the grain interiors grow at a relatively slow rate with domain sizes of just a few nanometers at $1100{ }^{\circ} \mathrm{C}$. When the $h$-AlN precipitates grow it means that there is further Al-enrichment of the Alrich $c$-TiCrAlN domains and further Al-depletion of the TiCr-rich $c$-TiCrAlN domains. But the Al-rich $c$-(TiCr)AlN domains are not stable, therefore there is a transformation into $h$-(Ti)AlN (containing traces of remaining Ti). 


\subsection{Oxidation behavior}

It has previously been shown that the oxidation resistance of $\mathrm{CrN}$ thin films can be improved through incorporation of $\mathrm{Al}[9,19-22]$. In particular, for magnetron sputtered $\mathrm{Cr}_{0.40} \mathrm{Al}_{0.60} \mathrm{~N}$ [23] it has been reported that the onset of oxidation occurs at $700{ }^{\circ} \mathrm{C}$ with a mass gain of $\sim 2 \%$ at $1100{ }^{\circ} \mathrm{C}$ using a heat rate of $20^{\circ} \mathrm{C} / \mathrm{min}$. As seen in the inset of Fig. 10 , using the same heating rate, the measured mass gain versus temperature is similar to those results for $\mathrm{Ti}_{0.01} \mathrm{Cr}_{0.39} \mathrm{Al}_{0.60} \mathrm{~N}$. But with a heating rate of $20{ }^{\circ} \mathrm{C} / \mathrm{min}$ the mass gain versus temperature for $\mathrm{Ti}_{0.11} \mathrm{Cr}_{0.28} \mathrm{Al}_{0.61} \mathrm{~N}$ is almost the equivalent to $\mathrm{Ti}_{0.01} \mathrm{Cr}_{0.39} \mathrm{Al}_{0.60} \mathrm{~N}$ indicating that the oxidation resistance is unaffected by the Ti addition. However with a slower heating rate providing more time for inwards diffusion of oxygen it becomes clear that the oxidation resistance is worsened with increasing Ti content. Here the pretective $\alpha-\mathrm{Al}_{2} \mathrm{O}_{3}$ is suppressed and instead $\mathrm{TiO}_{2}$ dominates. Crystalline or amorphous $\alpha-(\mathrm{CrAl})_{2} \mathrm{O}_{3}$ is known to be a good oxygen diffusion barrier [24] and the promotion of $\alpha-\mathrm{Al}_{2} \mathrm{O}_{3}$ in TiAlN has previously been suggested to be the reason for the improved oxygen resistance with increasing $\mathrm{Al}$ content observed in this system [25-27]. This is in agreement with the results presented here as the thin $\alpha-(\mathrm{CrAl})_{2} \mathrm{O}_{3}$ protective oxide layer is clearly more effective compared to $\mathrm{TiO}_{2}$ as seen in the samples with higher Ti content.

There is also another aspect of the $\mathrm{Ti}$ addition related to the formation of a protective oxide layer. The addition of Ti results in a delayed and suppressed nitrogen release and consequently also a delayed formation of $\beta-\mathrm{Cr}_{2} \mathrm{~N}$ and $b c c$-Cr. It has been suggested that the improved oxidation resistance seen when adding $\mathrm{Al}$ to $\mathrm{CrN}$ is related to an altered bond structure with stronger Al-N bonds, which suppress nitrogen release and stabilize the cubic structure [23]. However, in case of Ti additions to CrAlN the nitrogen release is 
also delayed and the cubic structure is also stabilized but at the same time the oxidation resistance becomes worse. Thus, this explanation can not be valid for TiCrAlN coatings. It has been shown that TiAlN coatings can exhibit a co-existence of $\mathrm{TiO}_{2}$ and $\alpha-\mathrm{Al}_{2} \mathrm{O}_{3}$ oxide layers where the structure contains two surface sublayers. $\alpha-\mathrm{Al}_{2} \mathrm{O}_{3}$ is located closest to the surface and $\mathrm{TiO}_{2}$ is formed below [28]. $\mathrm{TiO}_{2}$ formation is known to be associated with compressive stress generation during its formation leading to crack formation in the oxide layer [29] resulting in a degraded protection [27]. Eventually the $\mathrm{TiO}_{2}$ layer emerges to the surface and the oxidation increases rapidly [28]. This implies that, the microstructure affects the oxidation resistance significantly where for example the oxidation resistance varies with the coating density tuned by the substrate bias [28]. Therefore we account the decreased oxidation resistance to structural effects similar to those in TiAlN caused by the formation of $\mathrm{TiO}_{2}$.

Most striking is however, that $\mathrm{Ti}_{0.11} \mathrm{Cr}_{0.28} \mathrm{Al}_{0.61} \mathrm{~N}$ outperforms $\mathrm{Ti}_{0.33} \mathrm{Al}_{0.67} \mathrm{~N}$ both in terms of oxidation resistance and high temperature hardness since $\operatorname{Ti}_{0.33} \mathrm{Al}_{0.67} \mathrm{~N}$ today is one of the most frequently used high temperature wear protection coating composition. 


\section{Conclusions}

In this work we have demonstrated a concept of generating CrAlN coatings with improved mechanical properties through Ti addition. Low Ti, $\mathrm{x}<11$ at. $\%, \mathrm{Ti}_{\mathrm{x}} \mathrm{Cr}_{\mathrm{y}} \mathrm{Al}_{60} \mathrm{~N}$ coatings decompose via two different mechanisms. There are co-occurring processes of nucleation and growth constituting formation of incoherent $h$-AlN precipitates in the grain boundaries and spinodal decomposition of the grain interiors into $\mathrm{TiCr}$ - and $\mathrm{Al}$ - rich $c$-TiCrAlN. The spinodal decomposition of the grain interiors generates a hardness increase at elevated temperatures due to the obstruction of dislocation movements in the coating. With addition of Ti the formation and growth of $h$-AlN is suppressed and the cubic structure is stabilized. Altogether, this result in improved high temperature mechanical properties. The oxidation resistance is negatively affected by the Ti addition due to the promotion of a $\mathrm{TiO}_{2}$ surface layer over the more protective $\mathrm{Al}_{2} \mathrm{O}_{3}$. However for $\mathrm{Ti}_{0.11} \mathrm{Cr}_{0.28} \mathrm{Al}_{0.61} \mathrm{~N}$ both the mechanical properties and the oxidation resistance are superior compared to the commercially frequently used $\operatorname{Ti}_{0.33} \mathrm{Al}_{0.67} \mathrm{~N}$. 


\section{Acknowledgements}

This work was supported by the SSF project Designed multicomponent coatings, MultiFilms. We would like to acknowledge Dr. Jens Jensen at Linköping University for helping out with the compositional analysis (ERDA), Thomas Lingefelt at Linköping University for technical support regarding electron microscopy (TEM) and Pär Fogelqvist at SECO Tools AB for technical support of the deposition system. 


\section{References}

[1] J. Vetter, Surf. Coat. Technol. 76-77 (1995) 719.

[2] O. Knotek, M. Atzor, A. Barimani, F. Jungblut, Surf. Coat. Technol. 42 (1990) 21.

[3] H. Hasegawa, T. Suzuki, Surf. Coat. Technol. 188-189 (2004) 234.

[4] A.E. Reiter, V.H. Derflinger, B. Hanselmann, T. Bachmann, B. Sartory, Surf. Coat. Technol. 200 (2005) 2114.

[5] H. Willmann, P.H. Mayrhofer, L. Hultman, C. Mitterer, J. Mater. Res. 23 (2008) 2880.

[6] A. Hörling, L. Hultman, M. Odén, J. Sjölén, L. Karlsson, J. Vac. Sci. Technol. A 20 (2002) 1815.

[7] A. Hörling, L. Hultman, M. Odén, J. Sjölén, L. Karlsson, Surf. Coat. Technol. 191 (2005) 384.

[8] H.O. Gekonde, S.V. Subramanian, Surf. Coat. Technol. 149 (2002) 151.

[9] M. Kawate, A.K. Hashimoto, T. Suzuki, Surf. Coat. Technol. 165 (2003) 163.

[10] P.H. Mayrhofer, C. Mitterer, L. Hultman, H. Clemens, Prog. Mater. Sci. 51 (2006) 1032.

[11] R. Forsén, M. Johansson, M. Odén, N. Ghafoor, J. Vac. Sci. Technol. A 30 (2012) 061506.

[12] W.C. Oliver, G.M. Pharr, J. Mater. Res. 7 (1992) 1564.

[13] H. Lind, R. Forsén, B. Alling, N. Ghafoor, F. Tasnádi, M.P. Johansson, I.A. Abrikosov, M. Odén, Appl. Phys. Lett. 99 (2011) 091903.

[14] A. Knutsson, M.P. Johansson, L. Karlsson, M. Odén, J. Appl. Phys. 108 (2010) 044312 .

[15] M. Odén, J. Almer, G. Håkansson, M. Olsson, Thin Solid Films 377-378 (2000) 407.

[16] H. Willmann, P.H. Mayrhofer, P.O.Å. Persson, A.E. Reiter, L. Hultman, C. Mitterer, Scr. Mater. 54 (2006) 1847.

[17] P.H. Mayrhofer, A. Hörling, L. Karlsson, J. Sjölén, T. Larsson, C. Mitterer, L. Hultman, Appl. Phys. Lett. 83 (2003) 2049. 
[18] B. Alling, T. Marten, I.A. Abrikosov, A. Karimi, J. Appl. Phys. 102 (2007) 044314.

[19] J. Vetter, E. Lugscheider, S.S. Guerreiro, Surf. Coat. Technol. 98 (1998) 1233.

[20] O. Banakh, P.E. Schmid, R. Sanjinés, F. Lévy, Surf. Coat. Technol. 163-164 (2003) 57.

[21] R.J. Smith, C. Tripp, A. Knospe, C.V. Ramana, A. Kayani, V. Gorokhovsky, V. Shutthanandan, D.S. Gelles, J. Mater. Eng. Perform. 13 (2004) 295.

[22] E. Lugscheider, K. Bobzin, S. Bärwulf, T. Hornig, Surf. Coat. Technol. 133-134 (2000) 540 .

[23] J. Lin, B. Mishra, J.J. Moore, W.D. Sproul, Surf. Coat. Technol. 202 (2008) 3272.

[24] A.E. Reiter, C. Mitterer, B. Sartory, J. Vac. Sci. Technol. A 25 (2007) 711.

[25] H.A. Jehn, S. Hofmann, V. Ruckborn, W. Munz, J. Vac. Sci. Technol. A 4 (1986) 2701.

[26] O. Knotek, M. Bohmer, T. Leyendecker, J.Vac.Sci.Technol.A 4 (1986) 2695.

[27] L. Chen, J. Paulitsch, Y. Du, P.H. Mayrhofer, Surf. Coat. Technol. 206 (2012) 2954.

[28] D. McIntyre, J.E. Greene, G. Håkansson, J.-. Sundgren, W.-. Münz, J. Appl. Phys. 67 (1990) 1542.

[29] F. Vaz, L. Rebouta, M. Andritschky, M.F. Da Silva, J.C. Soares, Journal of the European Ceramic Society 17 (1997) 1971. 


\section{Figure captions}

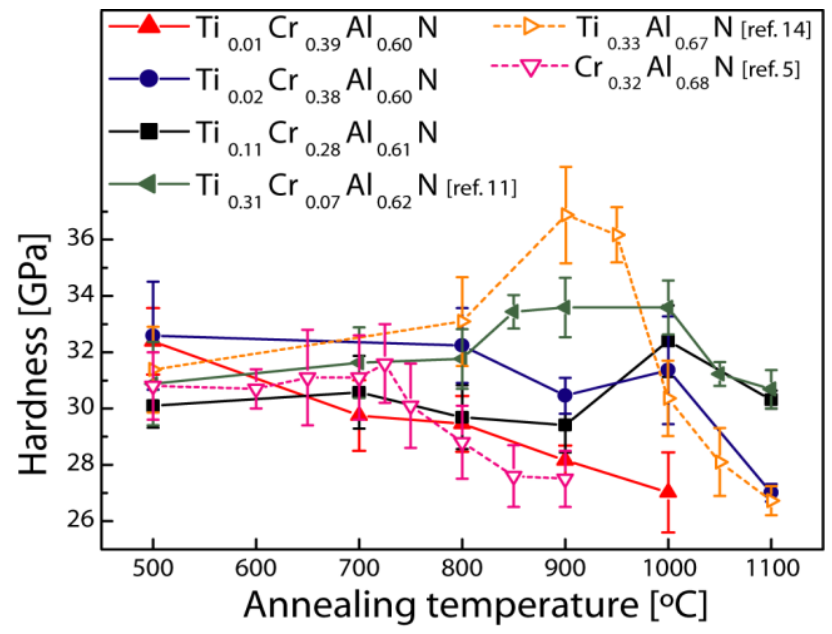

Figure 1 (color online) contains hardness results versus annealing temperature obtained with nanoindentation from $\quad \mathrm{Ti}_{0.01} \mathrm{Cr}_{0.39} \mathrm{Al}_{0.60} \mathrm{~N}, \quad \mathrm{Ti}_{0.02} \mathrm{Cr}_{0.38} \mathrm{Al}_{0.60} \mathrm{~N}, \quad \mathrm{Ti}_{0.11} \mathrm{Cr}_{0.28} \mathrm{Al}_{0.61} \mathrm{~N}, \quad \mathrm{Ti}_{0.31} \mathrm{Cr}_{0.07} \mathrm{Al}_{0.62} \mathrm{~N}$, $\mathrm{Ti}_{0.33} \mathrm{Al}_{0.67} \mathrm{~N}$ and $\mathrm{Cr}_{0.32} \mathrm{Al}_{0.68} \mathrm{~N}$.

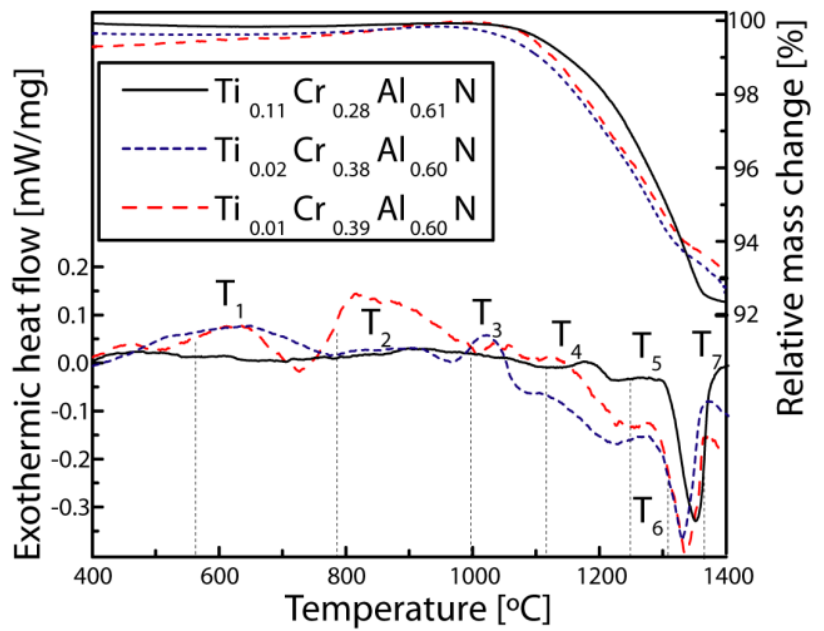

Figure 2 (color online) shows the in-situ DSC measurements of the thermal response of $\mathrm{Ti}_{0.11} \mathrm{Cr}_{0.28} \mathrm{Al}_{0.61} \mathrm{~N}$, $\mathrm{Ti}_{0.02} \mathrm{Cr}_{0.38} \mathrm{Al}_{0.60} \mathrm{~N}$ and $\mathrm{Ti}_{0.01} \mathrm{Cr}_{0.39} \mathrm{Al}_{0.60} \mathrm{~N}$ during heating up to $1400{ }^{\circ} \mathrm{C}$ with a heating rate of $20{ }^{\circ} \mathrm{C} / \mathrm{min}$. On the right axis the relative mass change during the heating process is given. The dashed vertical lines indicate where the derivative of the DSC signal is maximal for each respective peak. 

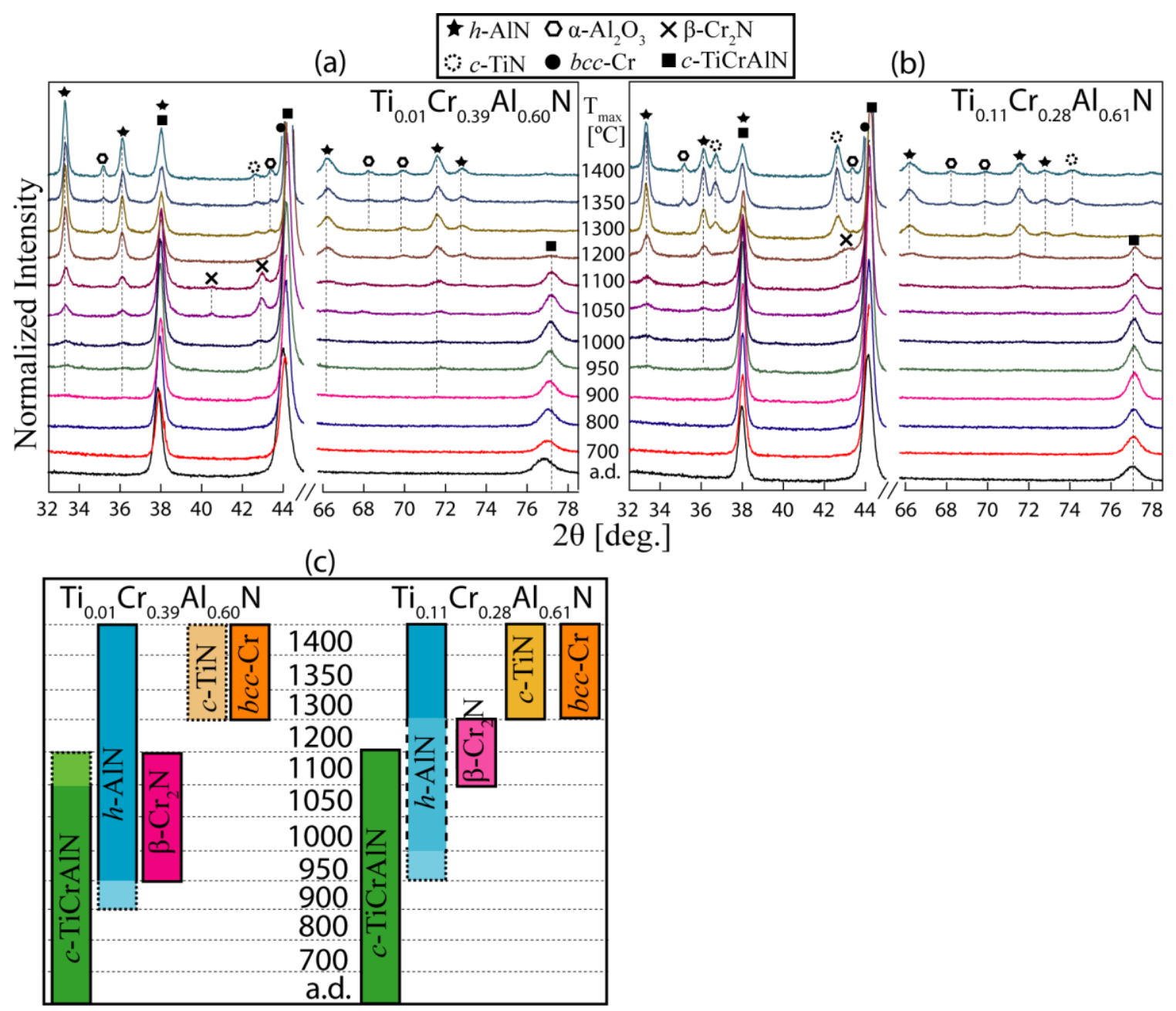

Figure 3 (color online) shows x-ray diffractograms of $\mathrm{Ti}_{0.01} \mathrm{Cr}_{0.39} \mathrm{Al}_{0.60} \mathrm{~N}$ (a) and $\mathrm{Ti}_{0.11} \mathrm{Cr}_{0.28} \mathrm{Al}_{0.61} \mathrm{~N}$ (b) in the $2 \theta$ range of $32^{\circ}$ to $45^{\circ}$ and from $66^{\circ}$ to $78^{\circ}$ at different temperatures. Fig. 3 (c) contains a schematic summary of the phase evolution. 


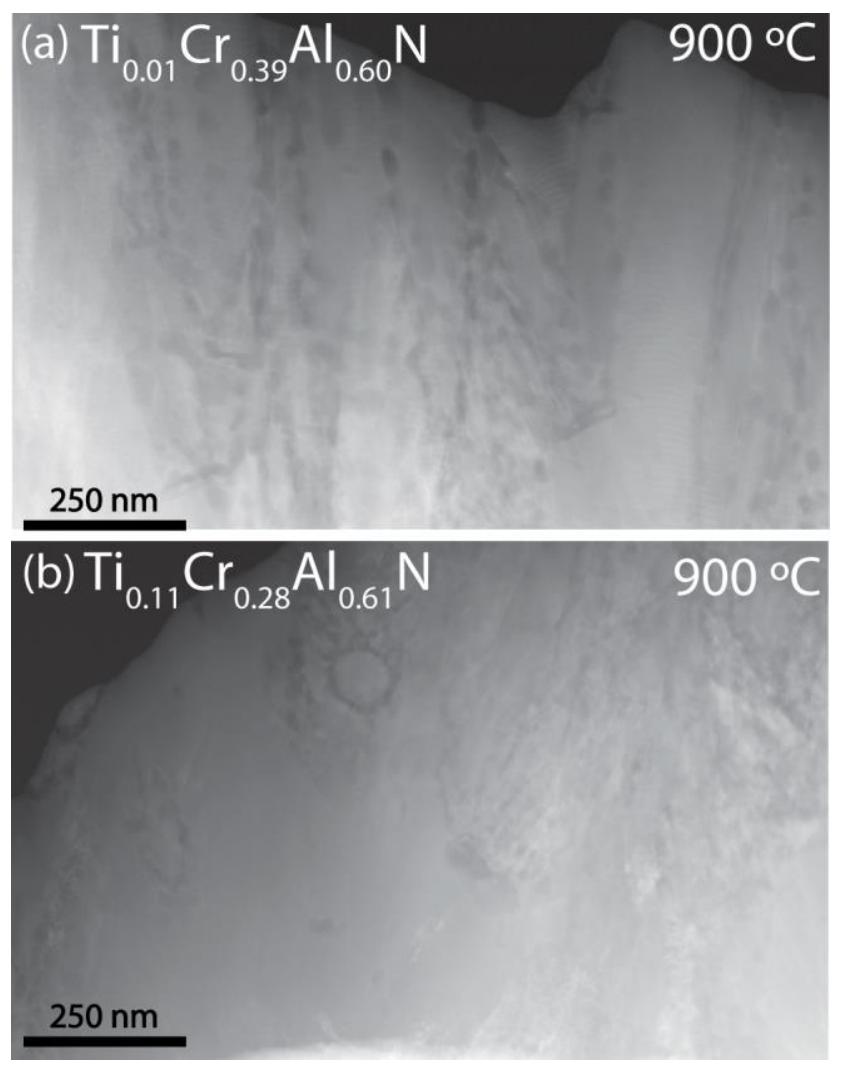

Figure 4 (a) and (b) show overview STEM Z-contrast micrographs of $\mathrm{Ti}_{0.01} \mathrm{Cr}_{0.39} \mathrm{Al}_{0.60} \mathrm{~N}$ and $\mathrm{Ti}_{0.11} \mathrm{Cr}_{0.28} \mathrm{Al}_{0.61} \mathrm{~N}$ annealed at $900{ }^{\circ} \mathrm{C}$ for 2 hours. 


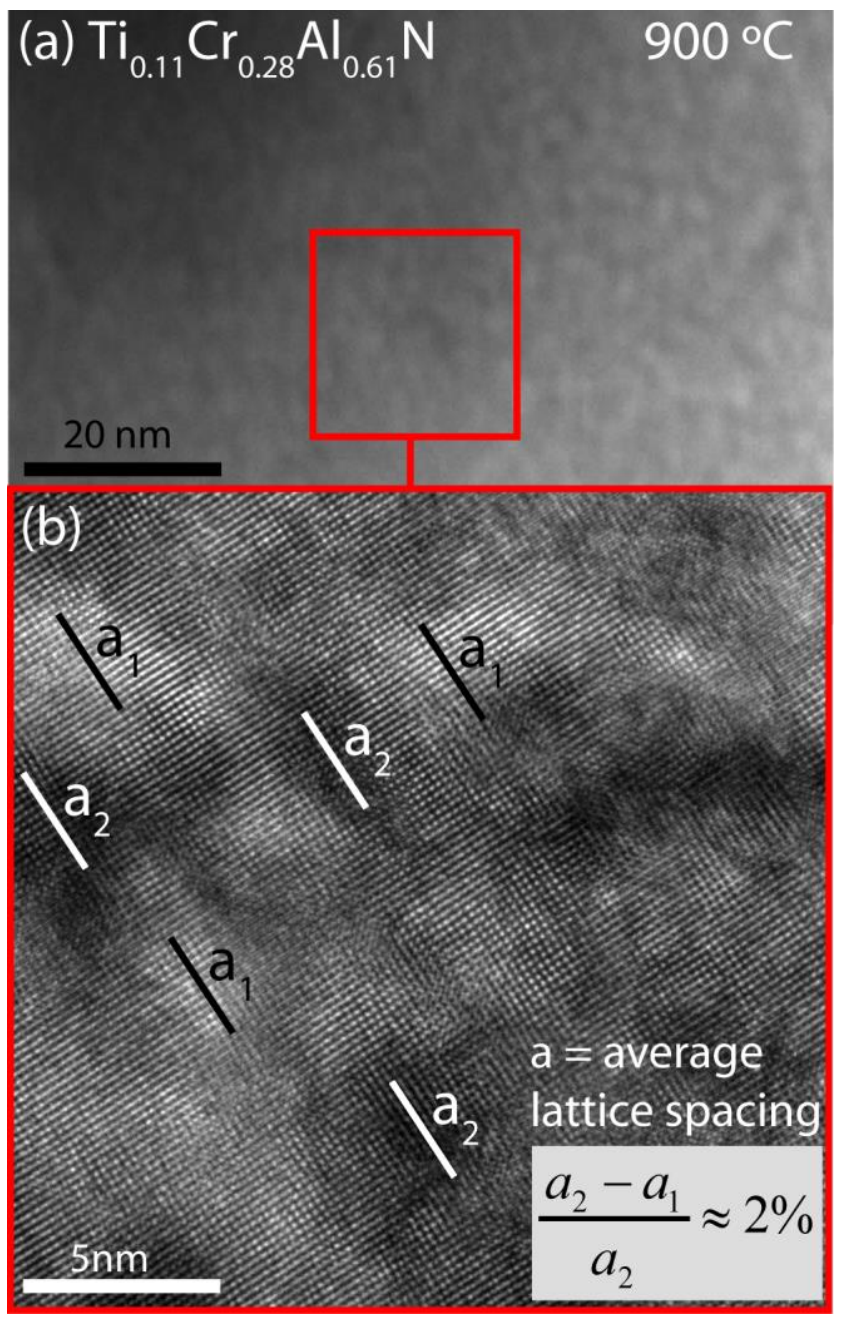

Figure 5 (color online) (a) shows a Z-contrast micrograph obtained from a grain interior for $\mathrm{Ti}_{0.11} \mathrm{Cr}_{0.28} \mathrm{Al}_{0.61} \mathrm{~N}$ annealed at $900{ }^{\circ} \mathrm{C}$. Fig. 5 (b) contains a high resolution micrograph with a higher magnification from the same region. 


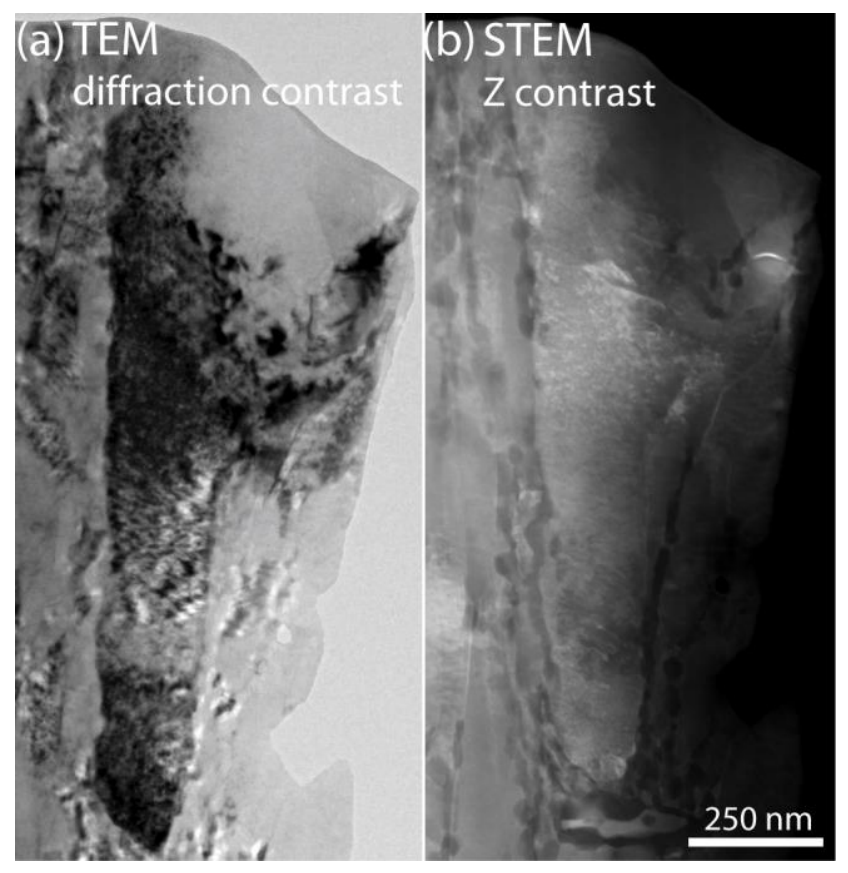

Figure 6 (a) and (b) show overview TEM and STEM micrographs of $\mathrm{Ti}_{0.11} \mathrm{Cr}_{0.28} \mathrm{Al}_{0.61} \mathrm{~N}$ annealed at 1000 ${ }^{\circ} \mathrm{C}$ for 2 hours. The arrows point at $\mathrm{Al}$ precipitation in the grain boundary. 


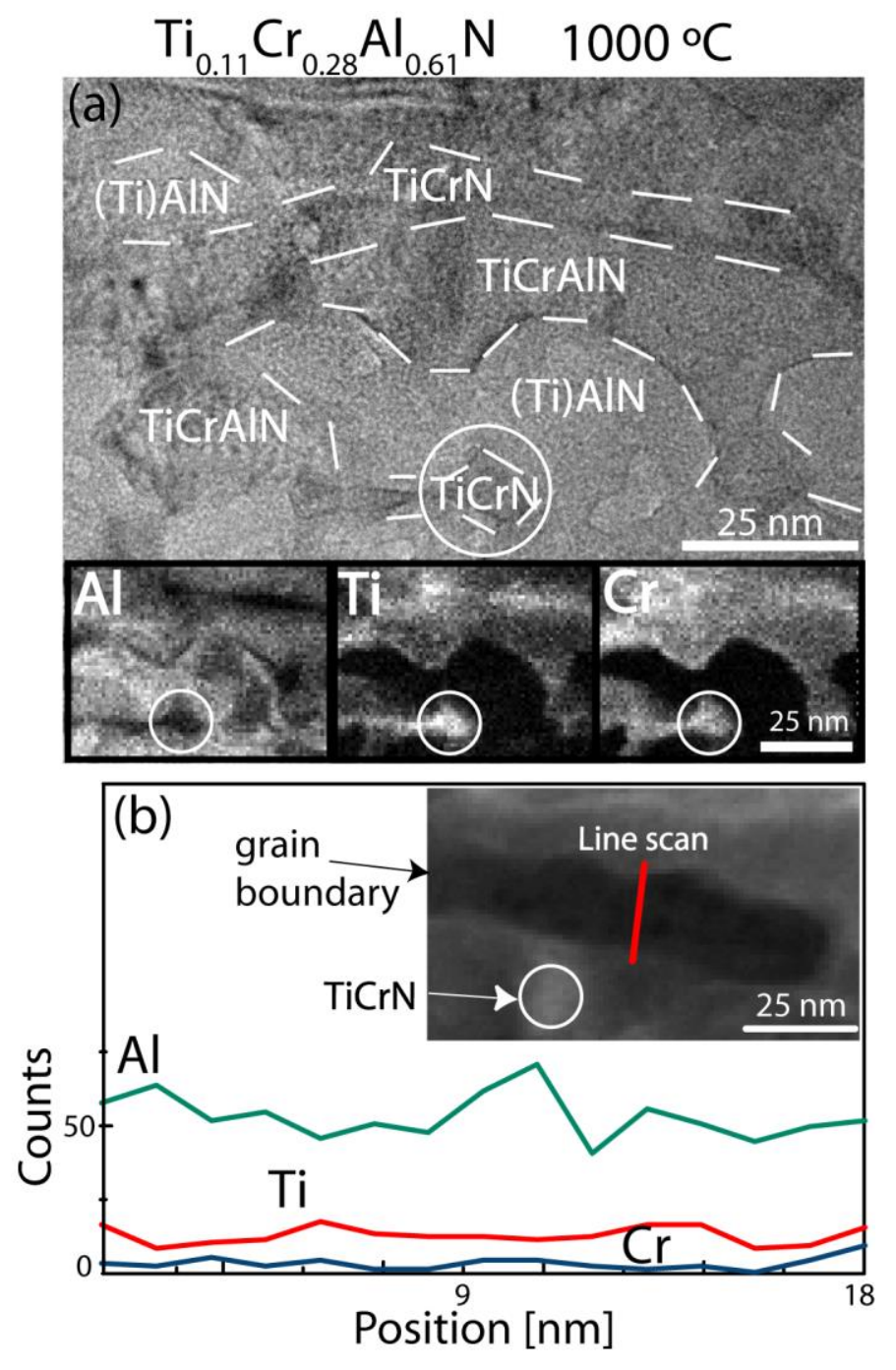

Figure 7 (color online) Upper part (a) shows a high resolution TEM micrograph of $\mathrm{Ti}_{0.11} \mathrm{Cr}_{0.28} \mathrm{Al}_{0.61} \mathrm{~N}$ annealed at $1000^{\circ} \mathrm{C}$ for 2 hours. The lower insets show maps from the same area of the characteristic x-ray signals from $\mathrm{Al}$, Ti and $\mathrm{Cr}$ respectively. Part (b) contains results from an EDX line scan across a grain boundary indicated by the dark region of the $\mathrm{Z}$ contrast micrograph obtained with STEM. The red line in the micrograph indicates where the line scan was obtained. 


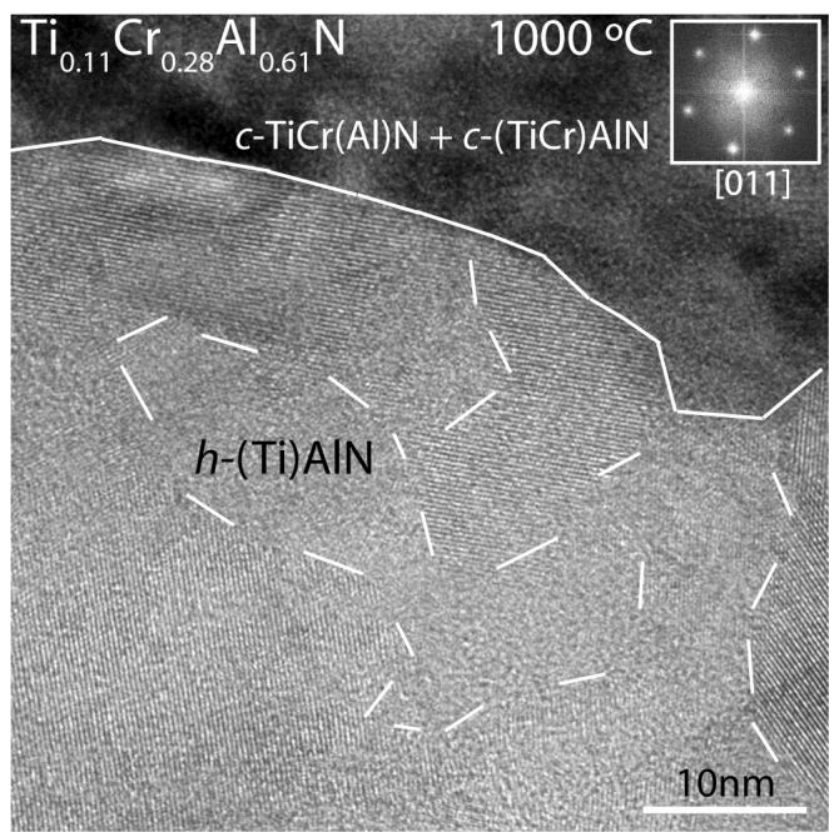

Figure 8 shows a high resolution micrograph of $\mathrm{Ti}_{0.11} \mathrm{Cr}_{0.28} \mathrm{Al}_{0.61} \mathrm{~N}$ annealed at $1000{ }^{\circ} \mathrm{C}$ for 2 hours. The white solid line indicates the domain boundary between $c$-TiCrAlN and $h$-(Ti)AlN. The dashed lines indicate the boundaries between different crystallites within the $h$-AlN-enriched domain. 


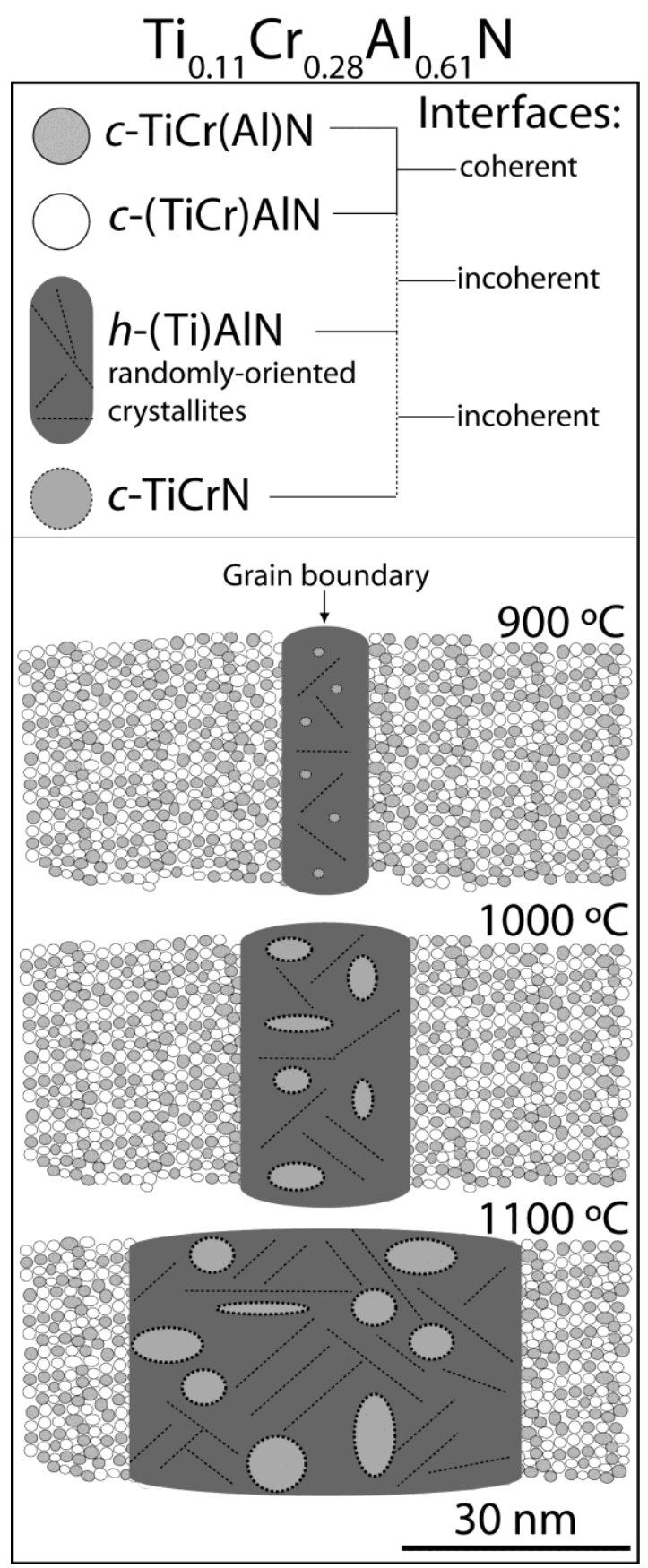

Figure 9 shows a model of the decompositions taking place in $\mathrm{Ti}_{0.11} \mathrm{Cr}_{0.28} \mathrm{Al}_{0.61} \mathrm{~N}$ upon annealing at temperatures of 900,1000 and $1100{ }^{\circ} \mathrm{C}$. The dark grey region depicts a grain boundary which is Alenriched with traces of Ti. The Al-enriched grain boundary contains randomly oriented crystallites indicated by the dashed lines. The grain boundary also contains Al-depleted $c$-TiCrN domains indicated by the dashed light grey areas. Within the two grains on each side of the grain boundary there are 2-5 nm sized compositional fluctuations corresponding to $\mathrm{TiCr}$ - and $\mathrm{Al}$-rich $c$-TiCrAlN. 


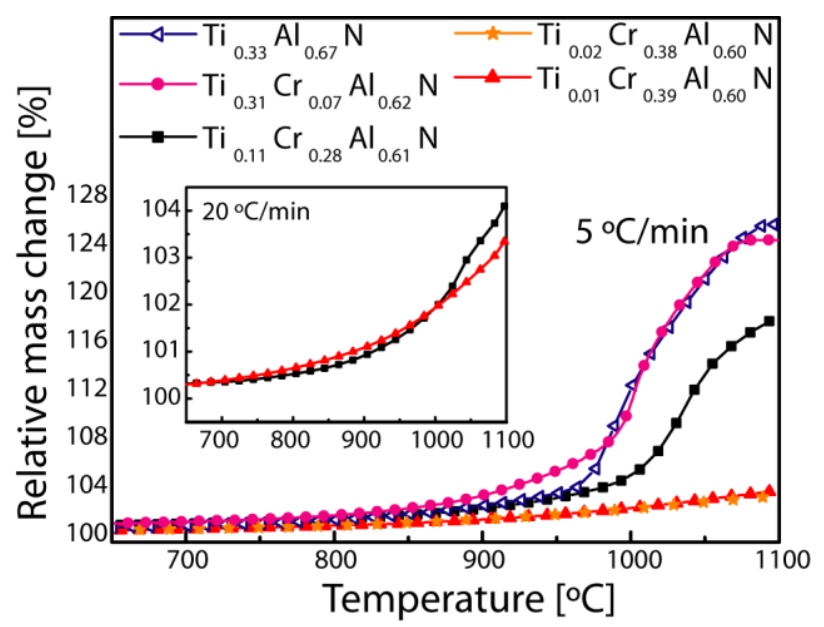

Figure 10 (color online) shows in-situ measurements of the mass change of powder $\operatorname{Ti}_{0.33} \mathrm{Al}_{0.67} \mathrm{~N}$, $\mathrm{Ti}_{0.31} \mathrm{Cr}_{0.07} \mathrm{Al}_{0.62} \mathrm{~N}, \mathrm{Ti}_{0.11} \mathrm{Cr}_{0.28} \mathrm{Al}_{0.61} \mathrm{~N}, \mathrm{Ti}_{0.02} \mathrm{Cr}_{0.38} \mathrm{Al}_{0.60} \mathrm{~N}$ and $\mathrm{Ti}_{0.01} \mathrm{Cr}_{0.39} \mathrm{Al}_{0.60} \mathrm{~N}$ during heating in air up to $1100{ }^{\circ} \mathrm{C}$ with a heating rate of $5{ }^{\circ} \mathrm{C} / \mathrm{min}$. The insets show the mass change of $\mathrm{Ti}_{0.11} \mathrm{Cr}_{0.28} \mathrm{Al}_{0.61} \mathrm{~N}$ and $\mathrm{Ti}_{0.01} \mathrm{Cr}_{0.39} \mathrm{Al}_{0.60} \mathrm{~N}$ using a heating rate of $20^{\circ} \mathrm{C} / \mathrm{min}$. 


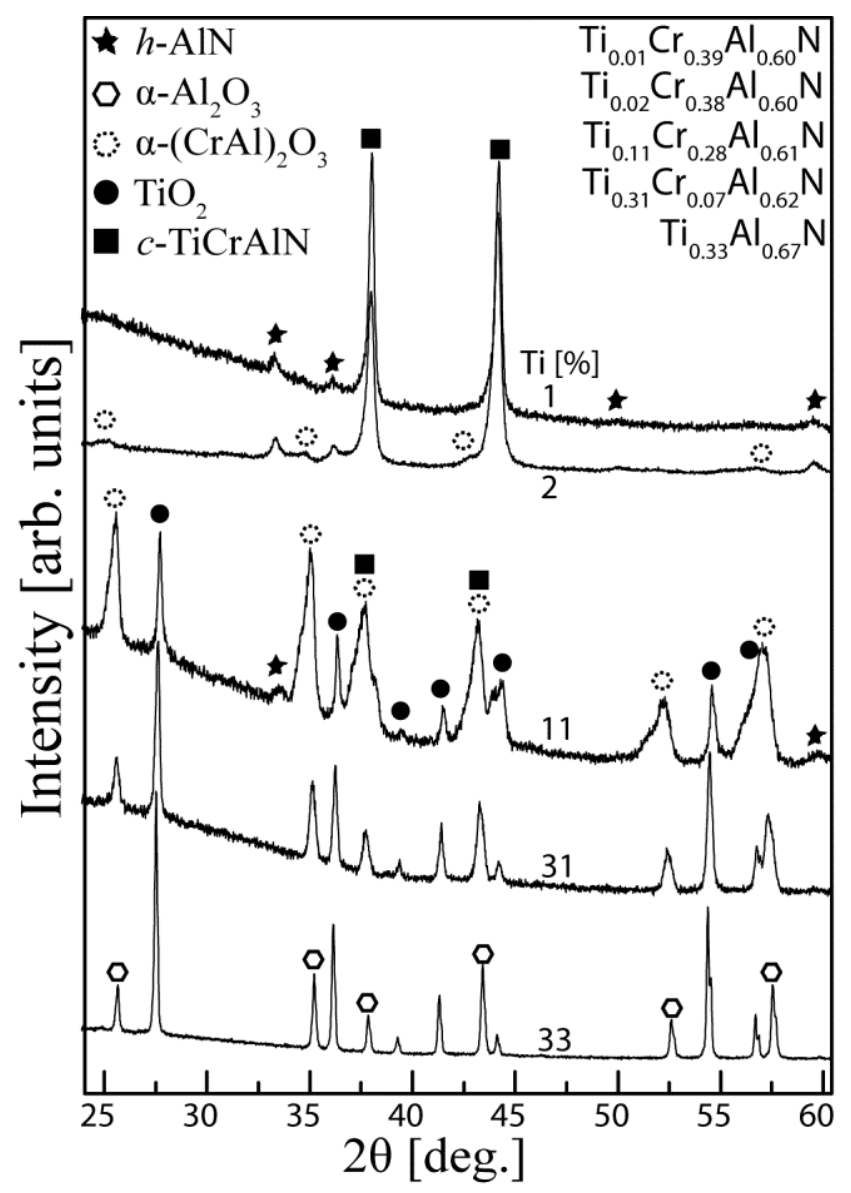

Figure 11 shows $x$-ray diffractograms of $\quad \mathrm{Ti}_{0.33} \mathrm{Al}_{0.67} \mathrm{~N}, \quad \mathrm{Ti}_{0.11} \mathrm{Cr}_{0.28} \mathrm{Al}_{0.61} \mathrm{~N}, \quad \mathrm{Ti}_{0.31} \mathrm{Cr}_{0.07} \mathrm{Al}_{0.62} \mathrm{~N}$, $\mathrm{Ti}_{0.02} \mathrm{Cr}_{0.38} \mathrm{Al}_{0.60} \mathrm{~N}$ and $\mathrm{Ti}_{0.01} \mathrm{Cr}_{0.39} \mathrm{Al}_{0.60} \mathrm{~N}$ in the $2 \theta$ range from $25^{\circ}$ to $60^{\circ}$ obtained after heating in air up to $1100{ }^{\circ} \mathrm{C}$ with a heating rate of $5{ }^{\circ} \mathrm{C} / \mathrm{min}$. 